\title{
LESÕES CUTÂNEAS EM FRANGOS DE CORTE: CARACTERÍSTICAS MORFOLÓGICAS E MOLECULARES*
}

\author{
LUIZ CESAR BELLO FALLAVENA
}

\author{
Carlos Tadeu Pippi Salle (Orientador - UFRGS) \\ Cláudio Wageck Canal (Co-Orientador - UFRGS)
}

Banca Examinadora:

Carlos Marcos Barcellos de Oliveira UFRGS

Paulo Soares da Costa UFF

Sérgio José de Oliveira ULBRA

Vladimir Pinheiro do Nascimento UFRGS

O crescimento da avicultura mundial vem ocorrendo significativamente nos últimos anos. Todavia, em função de modificações no processo de criação industrial dos frangos de corte, algumas enfermidades tornam-se cada vez mais importantes, como é o caso das cutâneas como a celulite, a varíola, o carcinoma dérmico de células escamosas (CDCE) e as dermatites inespecíficas. Como as lesões macroscópicas nessas doenças não são específicas, o diagnóstico na inspeção de carcaças é difícil, tendendo-se a agrupar as alterações cutâneas em uma categoria denominada "dermatose", o que inviabiliza a obtenção de dados relativos à prevalência das mesmas e o estudo dos fatores envolvidos na causa das mesmas. Esta tese consta de quatro artigos que relatam estudos sobre a ocorrência de lesões na pele de frangos de corte. No Artigo 1 descreve-se a ocorrência de casos de varíola atípica em frangos de corte no RGS, em que as lesões ocorreram nas áreas do corpo cobertas pelas penas, enquanto que no Artigo 2 relata-se o encontro de lesões semelhantes às do carcinoma dérmico de células escamosas (CDCE) associadas a lesões típicas de varíola em membranas cório-alantóides (M.C.A.) de ovos embrionados inoculados com preparados de amostras de pele contendo lesões de varíola ou de CDCE. O Artigo 3 relata os resultados dos exames histopatológicos em 800 amostras de pele de carcaças de frangos condenadas total ou parcialmente por lesões cutâneas em cinco matadouros do Estado (SIF 437: Caxias do Sul; SIF 730: Teutonia; SIF 1449: Lajeado; SIF 1661: Lajeado; SIF 2025: Porto Alegre). Histologicamente, 45,25\% foram diagnosticadas como celulite, $19,0 \%$ como varíola, $3,25 \%$ como CDCE, $17,0 \%$ como dermatite inespecífica, $0,5 \%$ como hemorragias focais e $0,25 \%$ como hemangioma. Do total de amostras, $14,75 \%$ não apresentaram alterações significativas. Macroscopicamente, as lesões mais freqüentes em todas as doenças diagnosticadas foram espessamento e alterações na coloração da pele, além de nódulos escuros nos folículos das penas e crostas. Arranhões na pele foram associados com todas as doenças diagnosticadas, à exceção do CDCE. Úlceras crateriformes ocorreram no CDCE e na varíola. A celulite foi mais freqüente na região abdominal, a varíola no dorso, o CDCE nas sobrecoxas e a dermatite inespecífica no dorso, sobrecoxas, coxas e peito. Concluiu-se que o exame histopatológico é ferramenta importante para a classificação adequada das doenças causadoras de lesões cutâneas. No Artigo 4 descreve-se protocolo de PCR ("nested PCR) para detecção específica de DNA de avipoxvírus, amplificando um fragmento do genoma do vírus contendo 419 pares de bases, sendo também mais sensível do que a técnica de inoculação na M.C.A. O DNA de poxvírus foi detectado em todas as amostras de pele com lesões de varíola, o mesmo não ocorrendo com doenças não relacionadas como varíola bovina, doença de Marek ou laringotraqueíte. Algumas amostras de pele macroscopicamente normais coletadas de carcaças de frangos vacinados ou não contra a varíola também produziram resultados positivos na PCR, corroborando estudos anteriores sobre a ocorrência de infecção latente. Detectou-se DNA de avipoxvírus nas lesões de CDCE de forma consistente, sendo os resultados discutidos no presente trabalho.

Descritores: lesões cutâneas, frangos de corte, características morfológicas e moleculares.

Apresentada: 5 novembro 2001

* Tese de Doutorado n.5 (Especialidade: Sanidade Avícola). 118f. Programa de Pós-Graduação em Ciências Veterinárias da Faculdade de Veterinária, Porto Alegre - UFRGS. CORRESPONDÊNCIA: L.C.B. Fallavena [e-mail: lcfallav@pro.via-rs.com.br]. 


\title{
SKIN LESIONS IN BROILER CHICKENS: MORPHOLOGICAL AND MOLECULAR CHARACTERISTICS**
}

\author{
LUIZ CESAR BELLO FALLAVENA
}

Carlos Tadeu Pippi Salle (Adviser - UFRGS)

Cláudio Wageck Canal (Co-Adviser - UFRGS)

Committee:

Carlos Marcos Barcellos de Oliveira UFRGS

Paulo Soares da Costa UFF

Sérgio José de Oliveira ULBRA

Vladimir Pinheiro do Nascimento UFRGS

The characteristics of the modern poultry industry, while providing better growth rates and production efficiency, have been associated with higher carcass condemnation rates due to the occurrence of important cutaneous diseases such as cellulitis, fowl pox, dermal squamous cell carcinoma (DSCC) and non-specific dermatitis. As the macroscopic lesions in these diseases are not specific, the classification of the cutaneous pathological processes at the slaughterhouses is difficult and, in many countries, skin lesions are grouped in one category named "dermatitis" or "dermatosis". One consequence is that important epidemiological data needed to study the factors involved in their causation remain unknown. This thesis presents four articles reporting the results of studies on the occurrence of skin lesions in broiler chickens. Article 1 describes the occurrence of atypical fowl pox cases in broiler chickens in the State of Rio Grande do Sul, in which the lesions were located in the feathered parts of the body, while Article 2 reports the finding of closely associated dermal squamous cell carcinoma (DSCC)-like lesions and pox lesions in chorioallantoic membranes (CAM) inoculated with skin samples presenting DSCC or pox lesions. Article 3 reports the results of a study in which eight hundred skin samples from broiler carcasses condemned or downgraded for skin lesions were collected at five federally inspected processing plants (SIF 437: Caxias do Sul; SIF 730: Teutonia; SIF 1449: Lajeado; SIF 1661: Lajeado; SIF 2025: Porto Alegre). Histologically, 45,25\% were cellulitis, 19,00\% were atypical fowl pox, 3,25\% were DSCC, $17,00 \%$ were non-specific dermatitis, $0,5 \%$ were focal haemorrhages and $0,25 \%$ were haemangiomas. Of the samples, $14,75 \%$ were histologically normal. Macroscopically, increased thickening of the skin was a frequent finding occurring in all the skin diseases, as well as skin discoloration, dark nodules in feather follicles and crusts. Skin scratches were associated with all of the diseases, except DSCC. Crater-like ulcers occurred in DSCC and fowl pox. Cellulitis was more frequent in the abdomen, fowlpox on the dorsum, DSCC in thighs, and non-specific dermatitis on the dorsum, thighs, legs and breast. It was concluded that macroscopic changes are not specific and examinations at slaughterhouses do not allow classification of broiler skin diseases. Histological examination appears to be an important tool to provide more accurate data. In Article 4, a sensitive and specific nested PCR protocol was developed which could amplify a 419 bp DNA fragment of fowl pox virus in a detection limit inferior to one egg infectious unit. Fowl pox DNA was always detected in skin samples with fowl pox lesions while it was not detected in samples of unrelated infectious diseases such as cowpox, Marek's disease or laryngotracheitis. Some macroscopically normal skin samples from vaccinated and non-vaccinated birds also produced PCR positive results, corroborating previous studies on the possibility that a latent or chronic form of fowl pox occurs. Fowl pox virus DNA was consistently detected from DSCC skin lesions and this finding is discussed.

Key words: skin lesions, broiler chickens, morfological and molecular characteristics.

Presented: 5 november 2001

**Doctoral Dissertation no.5 (Field: Avian Pathology). 118p. Postgraduate Program in Veterinary Sciences, Faculty of Veterinary Medicine, Porto Alegre - Federal University of Rio Grande do Sul (UFRGS)/Brazil. CORRESPONDENCE: L.C.B. Fallavena [e-mail: lcfallav@pro.via-rs.com.br]. 